\title{
Review Paper on Post-Tensioned Flat Slab with Drop Panels and Its Comparison with Conventional Slab
}

\author{
Soubhagya Ranjan Rath ${ }^{1}$, Susanta Kumar Sethy ${ }^{2}$ Mukesh Kumar Dubey ${ }^{3}$ \\ ${ }^{1}$ Student M. Tech Structure, ${ }^{2}$ Assistant Professor, ${ }^{3}$ Associate Professor, Civil Engineering department, \\ University of Petroleum and Energy Studies, Dehradun, India
}

\begin{abstract}
According to nowadays construction procedures of high rise buildings Post tension slabs and Flat slabs are both important cases of structure. PT slabs are able to carry almost all amount of dead load due to its tensioned tendons, which helps to carry out live load acting on slab and makes it's safer than conventional slabs. On the other hand Flat slabs with drop panels are having advantages like reduced building height, ease of formwork and faster construction procedure. Combination of Post-tensioned slab and Flat slab will be much more effective than usual slabs. These types of slabs also have advantages over conventional as per recent projects like high rise structures and long span frames as those are safe as per designing and give an aesthetic view for commercial or residential projects.
\end{abstract}

Keywords: post-tensioned flat slab, conventional slab, high rise building, building height, drop panels, Long span frames, load reduction, comparison between conventional and PT flat slab

\section{INTRODUCTION}

The necessity of high rise buildings increased in these days. Multi-story Buildings for the Commercial and also for the residential purpose should be designed such a way that it will be capable of sustaining more load than it is desired for as for the safety purpose. Some methods are followed for the safety factor of the building, aesthetic view and as well as economy in the net estimated cost for constructing it. Generally, there are many methods of slab of high rise building:-

1. Flat slab

2. Flat slab with drop panels

3. Waffle slab

4. Post-tensioned slab

5. Conventional slab ETC.

Here, considering both post-tensioned slab and flat slab together will be much more beneficial as compared to normal conventional RCC slab.

PT SLAB: - A concrete slab in which tendons are tensioned and then after released so that the compressive force acts on the slab cross-section.

FLAT SLAB: - It is a two-way reinforced concrete slab in which load is transferred from slab to column directly instead of providing beams.

DROP PANEL: - Drop panel is the projection below the slab which acts similar as beam and transfers load from slab to column in case of flat slab.

\section{LITERATURE REVIEW}

The buildings in which slab is directly supported by columns and drop panels have been considered in many buildings. Also, it has the benefit of being a reduction in the floor to floor height. Thin beams placed at regular intervals in perpendicular directions, thick slab used in case of the conventional slab. Considering the economic point of view, the PT flat slab is the most economical among all systems. If we compare the PT flat slab and conventional flat slab then the amount of reinforced concrete is around $15 \%$ greater and cost will be $30 \%$ greater than the post-tensioned flat slab. From both prospective PT floor system flat slab is much better than the PT slab with reinforced concrete beams in case of economy point of view. The required reinforcement in case of a posttensioned slab with reinforced concrete beams is more due to the provision of the beam which carries more load and need more reinforcement. Considering quantity of concrete required for a single floor is also more in case of a post-tensioned slab with reinforced concrete beams while it is least for the post-tensioned flat slab system. Considering construction period and formwork PT flat slab is advantageous than conventional slab Because In the case of the post-tensioned slab with reinforced concrete beams, the formwork of slab can be removed earlier but the formwork for the reinforced concrete beams cannot be removed earlier. In the case of post-tensioned slab some factored amount of dead load has been carried out and that is between 0.6 to 0.8 .

\section{COMPARATIVE STUDY BETWEEN CONVENTIONAL AND PT FLAT SLAB}

The comparative study of conventional and posttensioned flat slab have been described. Net weight of Post-tensioned Flat slab is quite low as compared to conventional slab structure. PT Flat slab structure is more economical than that of conventional slab structure as the cost of PT flat slab type structure is less than conventional slab type structures. Also Post- tension Flat slab structure leads to an aesthetic view which gives more floor height and it allows the architectural freedom of form works as compared to 


\section{International Journal of Research in Advent Technology, Vol.7, No.4, April}

2019

E-ISSN: 2321-9637

\section{Available online at www.ijrat.org}

conventional slab structure. Considering normal flat slab behaviour and conventional slab behaviour to axial and shear force, the difference has been shown below.

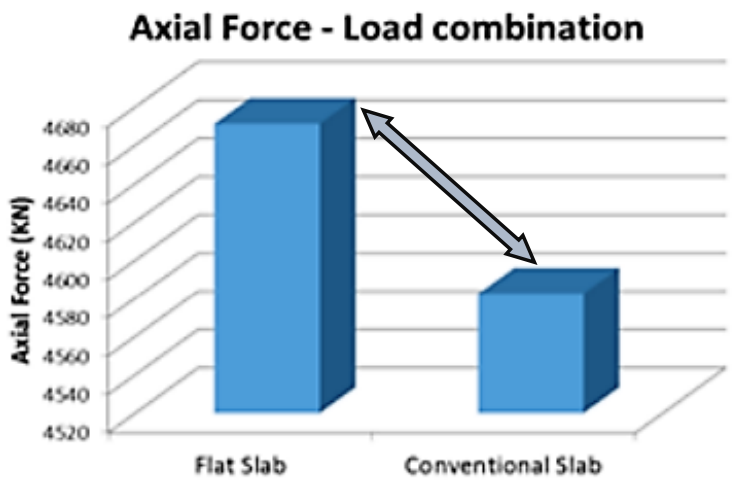

Shear Force - Load combination

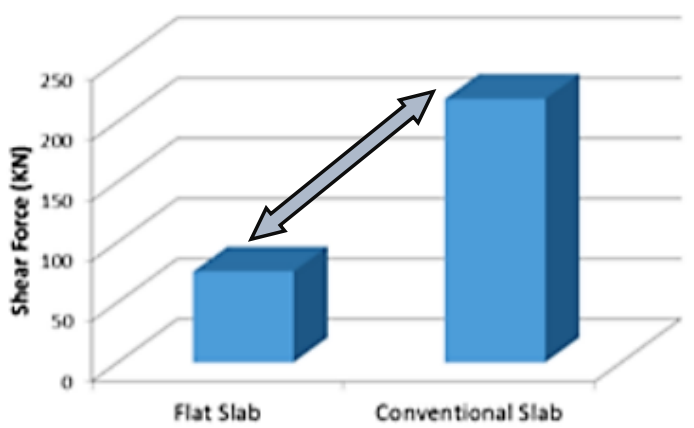

(Ref.FIG :Comparision between Flat slab and Conventional slab considering Axial and Shear force)

\subsection{Flat Slab Benefits}

- Provision of clear ceiling heights is greater.

- Ease of formwork and hence not costly.

- Flat ceiling gives attractive appearance or aesthetic view to the structure.

- Drop panel is provided instead of beams above column \& gives better illumination.

\subsection{Flat Slab Demerits}

- Longer span should not be more than 2.2 times of shorter span.

- Super imposed load on flat slab shall not exceed 3 times of design dead load.

- $\quad$ Slab thickness requirement is more in flat slab case and thickness of the slab should be more than $125 \mathrm{~mm}$.

- It's not flexible as compared to beam column conventional slab structure and less resistant towards the seismic effect.

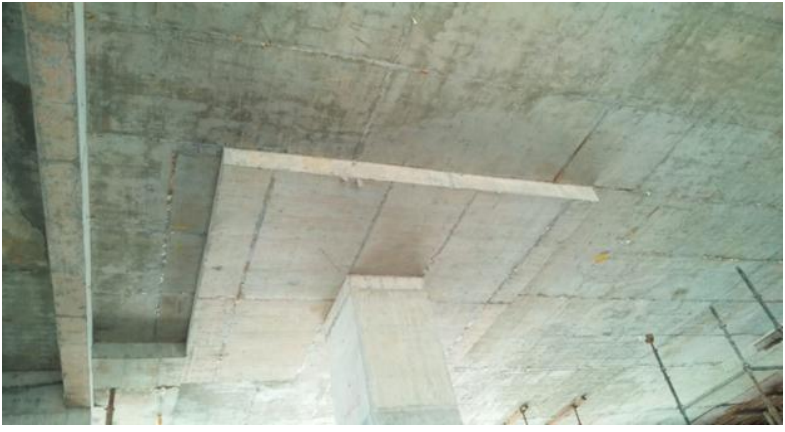

\subsection{Post-Tensioned Slab Benefits}

- For span having length above 6 to 6.7 meters, PT slabs are often more cost effective. Concrete quantity reductions up to one fourth i.e. $25 \%$, and typical rebar up to $65 \%$.

- In this case shoring and formwork can be removed as soon as the tendons are stressed or tensioned. This reduces the construction period by getting faster access to the lower floor.

- Detailed construction of post-tensioned slab results less permeable and less cracking.

- Span length up to 9 meters are commonly used for 2-way PT slab systems which allows more spacing of flexible tenant and better sightlines.

- Building net dead load and lateral-forceresistance structure which includes shear walls, columns and foundations are less because of thinner and lighter Post-tensioned slabs.

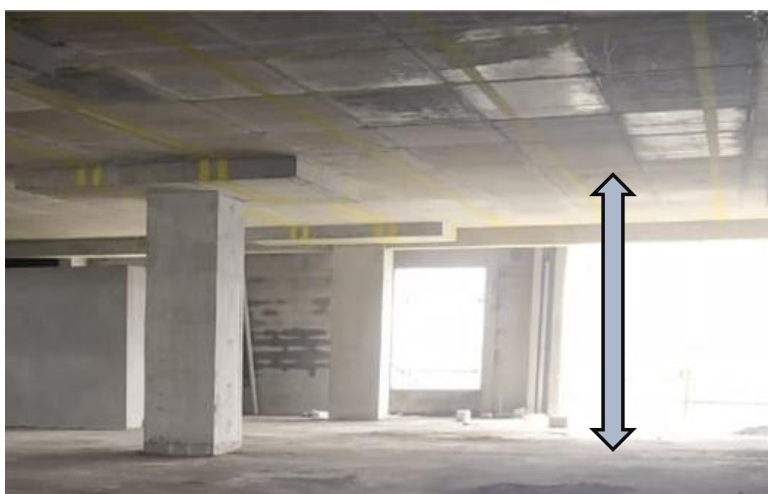

(Figure showing clearance in case of PT-flat slab with drop panels)

\subsection{Post-Tensioned Flat Slab}

The combination of both type of slabs will be much more beneficial as compared to the normal conventional slabs. As per the study the PT-flat slab merits and few demerits has been described.

\section{Benefits Of Post-Tensioned Flat Slab}

- It could be used for longer span as compared to normal flat slab.

- PT-Flat slab Improves flexibility as slabs are sleek and less space required. 


\section{International Journal of Research in Advent Technology, Vol.7, No.4, April 2019}

E-ISSN: 2321-9637

\section{Available online at www.ijrat.org}

- Seismic resistance in this case is also better due to more flexibility and provision of perimeter beams of flat slab.

- Slab thickness has been maintained due to post-tensioning.

- Simplifies construction, formwork, fastens the process of slab construction.

- Improved resistance toward Live load as posttensioning provides resistance of $60 \%-80 \%$ of Live load.

- Stronger structures are made at an affordable price by post-tensioning and slab becomes a feasible option in result we get economic construction of slab.

- It also reduces material usage in construction due to reduction of thickness, less structural members as compared to conventional.

- Durability of PT-flat slab is also better than usual slabs and it lasts longer.

\section{Drawbacks of Post-Tensioned Flat Slabs}

Now talking about few negative point to be considered in case of PT- Flat slab is described below

- As there are multiple tendons and wires spread inside the post tension slab, which may result in corrosion. But, the quality of tendons matters in case of corrosion.

- Due to the complexity of construction only skilful professional can manufacture posttensioned slabs. The local workers may not have the necessary knowledge skills required to make this complex slab.

- The main problem with using post tension slab is that if sufficient care is not taken while preparing it, it can lead to future fatal accidents. So workmanship should be good enough to get this work done.

\section{CONCLUSION}

Comparing conventional slab to post-tensioned flat slab, we getting results as PT flat slab is much more beneficial over beam column type conventional slab structures. It's economical, ease in construction, better for long span slabs, gives an aesthetic view, slab thickness maintained, more resistant towards live load, more seismic resistant and durable than conventional.

As per nowadays projects of high rise commercial or residential buildings, it's necessary to construct as per safety and as per workability of structure. The post-tensioned flat slab has more overall benefits compared to other types of slabs.

\section{REFERENCES}

[1]. Boskey Bahoria, Prof.R. S. Deotale ,Dr D K Parbat, "Comparative Design of RCC \& Post- tensioned flat slabs" Research Gate, 09-11 DECEMBER, 2010

[2]. Anusha. I. Koti, Dr. S. B. Vanakudre , "Analysis of PT flat slab with DropConsidering Seismic Effect" International Research Journal of Engineering and Technology, Volume: 05 Issue: 06 | June-2018

[3]. Kamal Padhiar, Dr. C.D. Modhera, Dr. A. K. Desai, "Comparative Parametric Study For Post-Tension Flat Slab And Flat Slab With Drop System" International Journal of Civil Engineering and Technology, Volume 8, Issue 5, May 2017

[4]. Shriraj S. Malvade, P.J. Salunke, "Analysis of Post-Tensioned Flat Slab by using SAFE" International Journal of Scientific Engineering and Applied Science,Volume-3, Issue-3, March 2017

[5]. Boskey Vishal Bahoria, Dhananjay K. Parbat, "Analysis and Design of RCC and Posttensioned Flat Slabs Considering Seismic Effect" International Journal of Engineering and Technology, Vol. 5, No. 1, February 2013

[6]. Amrut Manvi, Sandeep Gouripur, Pooja Sambrekar, Ramanjeet kaur, Dr. Kishor S. Kulkurni, "Cost Comparison Between Conventional And Flat Slab Structures", International Research Journal of Engineering and Technology, Volume: 02 Issue: 03 | June2015

[7]. Mohana H.S, Kavan M.R, “Comparative Study of Flat Slab and Conventional Slab Structure Using ETABS for Different Earthquake Zones of India" International Research Journal of Engineering and Technology, Volume: 02 Issue: 03 | June-2015 